\title{
An Analysis of the Social Profile of 15 to 17 Year Old Students in Ecuador Regarding Secondary School Attendance and Truancy
}

\author{
Lisa Gaye Williams Goodrich ${ }^{1}$, José Manuel Castellano ${ }^{1} \&$ Efstathios Stefos ${ }^{1}$ \\ ${ }^{1}$ National University of Education (UNAE), Azogues, Ecuador \\ Correspondence: Efstathios Stefos, National University of Education (UNAE), Azogues, Cañar, Parroquia Javier \\ Loyola (sector Chuquipata), Ecuador. Tel: 593-7-370-1200. E-mail: estefos@aegean.gr
}

Received: January 22, 2017

Accepted: February 6, 2017

Online Published: March 31, 2017

doi:10.5539/res.v9n2p91

URL: http://doi.org/10.5539/res.v9n2p91

\begin{abstract}
The objective of this study is to examine the factors influencing school attendance among the secondary school population between the ages of 15 and 17 in Ecuador, by means of a descriptive and multidimensional analysis of statistical data principally from the 2015 National Survey of Employment, Unemployment and Underemployment of Ecuador (ENEMDU). The descriptive analysis demonstrates the frequency and percentages of the variables used in the investigation, while comparing the social characteristics of student attendees and absentees in this age group. This descriptive analysis was conducted in order to provide a more enlightening profile of attendance and truancy regarding this sector of the student population whereas the method of multidimensional statistical analysis used was the hierarchical analysis which classifies the students in clusters according to their common traits.
\end{abstract}

Keywords: Ecuador, secondary school students, social profile, truancy

\section{Introduction}

In 2006 the Ecuadorian government, specifically the Ministry of Education and Culture, put together a ten-year plan referred to as the Decennial Plan of Education (El Plan Decenal de Educación) (MEC, 2006), to universalize access to primary, secondary and upper secondary education, increase the student population of upper secondary education, eradicate illiteracy, improve the quality of life of Ecuadorian citizens, contribute to the reduction of poverty and foment tolerance and respect for all ethnicities and nationalities that constitute Ecuador.

This plan may be considered a success if we focus on the marked increase in the number of adolescents between the ages of 12 and 17 who receive schooling. Case in point, in 2001, the percentage of 12 to 17 year olds of the lower class enrolled in school was as low as $51.6 \%$ compared to the figure of $80.2 \%$ in 2014 , similarly there has been improvement in this same age group among the middle and upper classes with an increase from $81.6 \%$ to $90.9 \%$ and $93.9 \%$ to $95.6 \%$ respectively (SITEAL, 2001/2014). However, one of the most effective ways to determine the validity of the educational system or student outcomes is by looking at the enrolment and attendance rates of the pupils (Rivers, 2010). These rates are seen as tangible evidence that education is reaching the sector of the population being targeted (UNICEF, 2011).

As a result, for this present study, we have chosen to focus on the teenage population of 15 to 17 years old (the three years of secondary education-Baccalaureate), as it is the age group that is likely to be under more pressure to support the family economically and consequently, changes in the drop out and attendance rate in this age group promise to be more marked. This study proposes to offer explanations as to why non-attendance occurs in addition to providing a socio-cultural analysis (or social profile) of the selected population of teenagers and of the factors which may or may not contribute to truancy among adolescents within this age group. It is hoped that this analysis will help us to better assess the improvements made to the Ecuadorian educational system over the past decade (Castellano et al., 2017).

\section{Method}

As mentioned before, the statistical information in this article is derived mainly from the 2015 National Survey of Employment, Unemployment and Underemployment of Ecuador (INEC, 2015), which, given the objective of the present study, led to the undertaking of a descriptive and a hierarchical analysis, with the former used to 
present, in a more simplified manner, the frequency and percentages of the variables under investigation (Papapostolou \& Stefos, 2013; Athanasiadis, 1995), and the latter, the hierarchical analysis, to illustrate the interrelationship between the variables of the survey while helping to define groups of people according to their shared characteristics. The hierarchical analysis is represented in a graph illustrating the classification that connects these clusters (Papapostolou et al., 2013). SPAD v 4.5 software, offered by the Faculty of Humanities of the University of the Aegean, was used to analyse the data.

\section{The Descriptive Analysis}

The percentage of students enrolled in school between the ages of 5 and $14(97.54 \%)$ is virtually the same as the percentage of the students of this age group who attend class (97.52\%). There is a high enrolment and attendance rate among the students of this age group (Tables $1 \& 2$ ).

Table 1. Enrolled in the school year 2015-2016 (ages 5-14)

\begin{tabular}{ccc}
\hline & $\mathrm{n}$ & $\%$ \\
\hline Yes & 3265205 & $97.54 \%$ \\
No & 82402 & $2.46 \%$ \\
Total & 3347607 & $100.00 \%$ \\
\hline
\end{tabular}

Table 2. Attend class (school year 2015-2016, ages 5-14)

\begin{tabular}{ccc}
\hline & $\mathrm{n}$ & $\%$ \\
\hline Yes & 3264503 & $97.52 \%$ \\
No & 83105 & $2.48 \%$ \\
Total & 3347607 & $100.00 \%$ \\
\hline
\end{tabular}

On the other hand, there has been a descent (roughly 12 percent less) in both enrolment and attendance in the 15 to 17 age group, although, similar to the students between the ages of 5 and 14 , the percentage of enrolled students $(85.44 \%)$ basically corresponds to the percentage of students who attend class (85.31\%) (Tables 3, 4 \& $5)$.

Table 3. Enrolled in school year 2015-2016 (ages 15-17)

\begin{tabular}{ccc}
\hline & $\mathrm{n}$ & $\%$ \\
\hline Yes & 842336 & $85.44 \%$ \\
No & 143549 & $14.56 \%$ \\
Total & 985885 & $100.00 \%$ \\
\hline
\end{tabular}

Table 4. Attend class (school year 2015-2016, ages 15-17)

\begin{tabular}{ccc}
\hline & $\mathrm{n}$ & $\%$ \\
\hline Yes & 841021 & $85.31 \%$ \\
No & 144864 & $14.69 \%$ \\
Total & 985885 & $100.00 \%$ \\
\hline
\end{tabular}

Table 5. Enrolled in school year 2015-2016 (ages 15-17)

\begin{tabular}{ccccc}
\hline & \multicolumn{2}{c}{ Attend class } & \multicolumn{2}{c}{ Do not attend class } \\
\cline { 2 - 5 } & $\mathrm{n}$ & $\%$ & $\mathrm{n}$ & $\%$ \\
\hline Yes & 838735 & $99.73 \%$ & 3601 & $2.49 \%$ \\
No & 2286 & $0.27 \%$ & 141263 & $97.51 \%$ \\
Total & 841021 & $100.00 \%$ & 144864 & $100.00 \%$ \\
\hline
\end{tabular}


Comparatively speaking, the majority of the students who attend class are from urban areas $(67.74 \%)$, which is more than twice the percentage of those who attend class from rural areas $(32.26 \%)$. Yet, in the variable of non-attendance, the urban and rural areas had similar percentages $49.46 \%$ and $50.24 \%$ respectively (Table 6).

Table 6. Area (ages 15-17)

\begin{tabular}{ccccc}
\hline & \multicolumn{2}{c}{ Attend class } & \multicolumn{2}{c}{ Do not attend class } \\
\cline { 2 - 5 } & $\mathrm{n}$ & $\%$ & $\mathrm{n}$ & $\%$ \\
\hline Urban & 569732 & $67.74 \%$ & 72082 & $49.76 \%$ \\
Rural & 271289 & $32.26 \%$ & 72782 & $50.24 \%$ \\
Total & 841021 & $100.00 \%$ & 144864 & $100.00 \%$ \\
\hline
\end{tabular}

Regarding gender, more boys (51.93\%) than girls (48.17\%) attend class, although this difference between the sexes is minimal (Table 7). However, taking into consideration that $2.47 \%$ (Table 8 ) of the population studied, cited "pregnancy" as a reason for not attending class, and that as much as $12.95 \%$ of the girls who become pregnant or are in the period of lactation (Table 9), do not attend class, it may be reasonable to assume that a contributing factor to the lower attendance of girls compared to that of boys, could be related to pregnancy and child-rearing (in addition to other social factors regarding gender). Overall, however, the data shows that the predominant reason for not attending class is the lack of economic resources $(32.54 \%)$, followed by a lack of interest $(15.70 \%)$, work $(11.31 \%)$, housework $(10.08 \%)$, disease or disability $(5.86 \%)$ and the lack of permission from the family $(4.38 \%)$.

Table 7. Sex (ages 15-17)

\begin{tabular}{ccccc}
\hline & \multicolumn{2}{c}{ Attend class } & \multicolumn{2}{c}{ Do not attend class } \\
\cline { 2 - 5 } & $\mathrm{n}$ & $\%$ & $\mathrm{n}$ & $\%$ \\
\hline Male & 436705 & $51.93 \%$ & 69777 & $48.17 \%$ \\
Female & 404315 & $48.07 \%$ & 75087 & $51.83 \%$ \\
Total & 841021 & $100.00 \%$ & 144864 & $100.00 \%$ \\
\hline
\end{tabular}

Table 8. Reason for not attending class (ages 15-17)

\begin{tabular}{ccc}
\hline & $\mathrm{n}$ & $\%$ \\
\hline Age & 619 & $0.43 \%$ \\
Finished studies & 1315 & $0.91 \%$ \\
No money & 47134 & $32.54 \%$ \\
School failure & 5557 & $3.84 \%$ \\
Work & 16384 & $11.31 \%$ \\
Disease or disability & 8495 & $5.86 \%$ \\
House work & 14597 & $10.08 \%$ \\
Not permitted by family & 6339 & $4.38 \%$ \\
No educational institutions in the area & 754 & $0.52 \%$ \\
Not interested & 22741 & $15.70 \%$ \\
Pregnancy & 3576 & $2.47 \%$ \\
No space in schools & 3229 & $2.23 \%$ \\
Other & 14124 & $9.75 \%$ \\
Total & 144864 & $100.00 \%$ \\
\hline
\end{tabular}


Table 9. Pregnant or in the lactation period (ages 15-17)

\begin{tabular}{ccccc}
\hline & \multicolumn{2}{c}{ Attend class } & \multicolumn{2}{c}{ Do not attend class } \\
\hline & $\mathrm{n}$ & $\%$ & $\mathrm{n}$ & $\%$ \\
Yes & 10184 & $1.21 \%$ & 18754 & $12.95 \%$ \\
No & 394132 & $46.86 \%$ & 56333 & $38.89 \%$ \\
NA & 436705 & $51.93 \%$ & 69777 & $48.17 \%$ \\
Total & 841021 & $100.00 \%$ & 144864 & $100.00 \%$ \\
\hline
\end{tabular}

In terms of age, 15 year olds have the lowest incidence of non-attendance (19.67\%), while the 17 year olds, the highest (48.10\%) (Table 10).

Table 10. Age

\begin{tabular}{ccccc}
\hline & \multicolumn{2}{c}{ Attend class } & \multicolumn{2}{c}{ Do not attend class } \\
\cline { 2 - 5 } & $\mathrm{n}$ & $\%$ & $\mathrm{n}$ & $\%$ \\
\hline 15 & 326776 & $38.85 \%$ & 28489 & $19.67 \%$ \\
16 & 287863 & $34.23 \%$ & 46694 & $32.23 \%$ \\
17 & 226382 & $26.92 \%$ & 69681 & $48.10 \%$ \\
Total & 841021 & $100.00 \%$ & 144864 & $100.00 \%$ \\
\hline
\end{tabular}

The fact that there is less attendance as the subjects get older could be related to an increase in responsibilities, such as more housework or work resulting from a possible necessity or expectation on the part of the rest of the family members that the older teen contribute to the family income (Colbert de Arboleda et al., 1994). Additionally, it is possible that the older the subjects become the likelihood that they will form families of their own, given that as high as $21.64 \%$ are in common-law union (Table 11 ).

Table 11. Marital status (ages 15-17)

\begin{tabular}{ccccc}
\hline & \multicolumn{2}{c}{ Attend class } & \multicolumn{2}{c}{ Do not attend class } \\
\cline { 2 - 5 } & $\mathrm{n}$ & $\%$ & $\mathrm{n}$ & $\%$ \\
\hline Married & 6806 & $0.81 \%$ & 1767 & $1.22 \%$ \\
Separated & 1911 & $0.23 \%$ & 2562 & $1.77 \%$ \\
Divorced & 1332 & $0.16 \%$ & 160 & $0.11 \%$ \\
Widowed & 47 & $0.01 \%$ & 0 & $0.00 \%$ \\
Common-law union & 11975 & $1.42 \%$ & 31355 & $21.64 \%$ \\
Single & 818950 & $97.38 \%$ & 109019 & $75.26 \%$ \\
Total & 841021 & $100.00 \%$ & 144864 & $100.00 \%$ \\
\hline
\end{tabular}

The majority of the students surveyed attend class in the morning $(70.77 \%)$, followed by $25.28 \%$ who attend class during the evening. A very small percentage (1.74\%) attend class at night with a slightly higher percentage doing distance learning (1.80\%) (Table 12). 
Table 12. Shift attended (ages 15-17)

\begin{tabular}{ccc}
\hline & $\mathrm{n}$ & $\%$ \\
\hline Morning & 595158 & $70.77 \%$ \\
Evening & 212611 & $25.28 \%$ \\
Night & 14625 & $1.74 \%$ \\
Full day & 169 & $0.02 \%$ \\
Two full days & 3300 & $0.39 \%$ \\
Distance learning & 15157 & $1.80 \%$ \\
Total & 841021 & $100.00 \%$ \\
\hline
\end{tabular}

In terms of language, the vast majority speak only Spanish (91.47\%), so it is safe to assume that attendance is not affected by a language barrier (Table 13).

Table 13. Language spoken (ages 15-17)

\begin{tabular}{ccccc}
\hline & \multicolumn{2}{c}{ Attend class } & \multicolumn{2}{c}{ Do not attend class } \\
\cline { 2 - 5 } & $\mathrm{n}$ & $\%$ & $\mathrm{n}$ & $\%$ \\
\hline Only indigenous language & 140 & $0.02 \%$ & 0 & $0.00 \%$ \\
Indigenous language and Spanish & 50768 & $6.04 \%$ & 10302 & $7.11 \%$ \\
Only Spanish & 780599 & $92.82 \%$ & 132500 & $91.47 \%$ \\
Spanish and foreign language & 7903 & $0.94 \%$ & 505 & $0.35 \%$ \\
Indigenous and foreign language & 530 & $0.06 \%$ & 0 & $0.00 \%$ \\
Foreign language & 771 & $0.09 \%$ & 0 & $0.00 \%$ \\
Do not speak & 309 & $0.04 \%$ & 1556 & $1.07 \%$ \\
Total & 841021 & $100.00 \%$ & 144864 & $100.00 \%$ \\
\hline
\end{tabular}

The majority of the subjects surveyed who attend class identified themselves as "mestizo" (79.65\%), followed by $9.56 \%$ who considered themselves indigenous and about half that percentage (4.72\%) thought of themselves as Montubio (Table 14).

Table 14. How the subjects identify themselves (ages 15-17)

\begin{tabular}{ccccc}
\hline & \multicolumn{2}{c}{ Attend class } & \multicolumn{2}{c}{ Do not attend class } \\
\cline { 2 - 5 } & $\mathrm{n}$ & $\%$ & $\mathrm{n}$ & $\%$ \\
\hline Indigenous people & 80428 & $9.56 \%$ & 17704 & $12.22 \%$ \\
Afro-Ecuadorian & 7917 & $0.94 \%$ & 2023 & $1.40 \%$ \\
Black & 18659 & $2.22 \%$ & 3241 & $2.24 \%$ \\
Mulatto & 11437 & $1.36 \%$ & 1795 & $1.24 \%$ \\
Montubio & 39702 & $4.72 \%$ & 12886 & $8.90 \%$ \\
Mestizo & 669849 & $79.65 \%$ & 104368 & $72.05 \%$ \\
White & 12741 & $1.51 \%$ & 2847 & $1.97 \%$ \\
Other & 288 & $0.03 \%$ & 0 & $0.00 \%$ \\
Total & 841021 & $100.00 \%$ & 144864 & $100.00 \%$ \\
\hline
\end{tabular}


Logically since the sample population came from the age group of 15 to 17 year olds, there is an underrepresentation in the category of "pensioner", both in terms of attendance $(0.002 \%)$ and non-attendance $(0.16 \%)$ (Table 15$)$. The overwhelming majority of the subjects who attend class are logically students $(90.03 \%)$, while the majority of those who do not attend class, almost half of the surveyed population $(46.41 \%)$, are not students but rather teenagers who do not find any of the categories (pensioner, student, housewife, disabled, other) applicable. Interestingly, the second highest percentage of those who do not attend class, comes from the category of housewife $(27.76 \%)$, followed closely by $20.06 \%$ who stated their status of inactivity as "other". Disability $(5.62 \%)$ was not a principal reason for not attending class.

Table 15. Status of inactivity (ages 15-17)

\begin{tabular}{ccccc}
\hline & \multicolumn{2}{c}{ Attend class } & \multicolumn{2}{c}{ Do not attend class } \\
\cline { 2 - 5 } & $\mathrm{n}$ & $\%$ & $\mathrm{n}$ & $\%$ \\
\hline Pensioner & 17 & $0.002 \%$ & 225 & $0.16 \%$ \\
Student & 759453 & $90.30 \%$ & 0 & $0.00 \%$ \\
Housewife & 0 & $0.00 \%$ & 40208 & $27.76 \%$ \\
Disabled & 0 & $0.00 \%$ & 8141 & $5.62 \%$ \\
Other & 455 & $0.05 \%$ & 29059 & $20.06 \%$ \\
NA & 81096 & $9.64 \%$ & 67231 & $46.41 \%$ \\
Total & 841021 & $100.00 \%$ & 144864 & $100.00 \%$ \\
\hline
\end{tabular}

The majority of the subjects who attend class do not find any of the categories of this job-related variable applicable, which would seem coherent given that it is a population sample from the age group of 15 to 17 year olds and who are therefore not likely to be well represented in job related issues (Table 16). Despite this, however, over $50 \%$ of the surveyed subjects who attend class do not find the categories in this variable applicable to their situation. On the other hand, it also follows that $27.76 \%$ of those who do not attend class are happy with their jobs compared to an $8.32 \%$ who are happy with their jobs and attend class. It would make sense that there is a higher percentage of non-attendance among those who are happy with their jobs, since the level of happiness at work could inversely affect the level of interest in school. That said, the percentage of those who attend class and are happy with their jobs (8.32\%) is roughly the same as that of those who do not attend class and are unhappy with their jobs (8.64\%). This would suggest that happiness at work affects more the level of non-attendance ( $27.76 \%$ of those who do not attend class are happy at work) than it does the level of attendance, and being miserable at work has no great impact on the attendance of classes.

Table 16. The level of happiness at work (ages 15-17)

\begin{tabular}{ccccc}
\hline & \multicolumn{2}{c}{ Attend class } & \multicolumn{2}{c}{ Do not attend class } \\
\cline { 2 - 5 } & $\mathrm{n}$ & $\%$ & $\mathrm{n}$ & $\%$ \\
\hline Happy & 69946 & $8.32 \%$ & 40215 & $27.76 \%$ \\
Not very happy & 6109 & $0.73 \%$ & 12516 & $8.64 \%$ \\
Unhappy but conformant & 3647 & $0.43 \%$ & 5006 & $3.46 \%$ \\
Completely unhappy & 253 & $0.03 \%$ & 1738 & $1.20 \%$ \\
NA & 761065 & $90.49 \%$ & 85389 & $58.94 \%$ \\
Total & 841021 & $100.00 \%$ & 144864 & $100.00 \%$ \\
\hline
\end{tabular}

Interestingly, the highest percentage of attendance is represented by the subjects in public schools $(81.17 \%)$ whereas as low as a quarter of those who attend school (14.54\%) are from private institutions (Table 17). This could mean that public schools have a stricter policy of school attendance although more data is needed to determine whether or not the majority of the sample population come from public schools, that is, if there is an equal representation of public and private schools in the survey. 
Table 17. The institute in which they are enrolled

\begin{tabular}{ccccc}
\hline & \multicolumn{2}{c}{ Attend class } & \multicolumn{2}{c}{ Do not attend class } \\
\cline { 2 - 5 } & $\mathrm{n}$ & $\%$ & $\mathrm{n}$ & $\%$ \\
\hline Public & 682657 & $81.17 \%$ & 3445 & $2.38 \%$ \\
Private & 122267 & $14.54 \%$ & 156 & $0.11 \%$ \\
Semi-private, municipal & 33811 & $4.02 \%$ & 0 & $0.00 \%$ \\
NA & 2286 & $0.27 \%$ & 141263 & $97.51 \%$ \\
Total & 841021 & $100.00 \%$ & 144864 & $100.00 \%$ \\
\hline
\end{tabular}

Approximately $54.4 \%$ of the 15 to 17 year olds who attend class do not have an activated cellular phone, while a slightly higher percentage of those who do not attend class, do not have an activated cellular phone (58.93\%). That is, not having a cellular phone would seem to have affected attendance in a negative way, although the difference between percentages is too small to make any assumptions (Table 18).

Table 18. Have an activated cellular phone (ages 15-17)

\begin{tabular}{ccccc}
\hline & \multicolumn{2}{c}{ Attend class } & \multicolumn{2}{c}{ Do not attend class } \\
\cline { 2 - 5 } & $\mathrm{n}$ & $\%$ & $\mathrm{n}$ & $\%$ \\
\hline Yes & 360545 & $42.87 \%$ & 52600 & $36.31 \%$ \\
No & 457523 & $54.40 \%$ & 85361 & $58.93 \%$ \\
NA & 22953 & $2.73 \%$ & 6902 & $4.76 \%$ \\
Total & 841021 & $100.00 \%$ & 144864 & $100.00 \%$ \\
\hline
\end{tabular}

In general, however, there are less teenagers who attend class who have access to cellular phones (42.87\%) than those who attend class and do not (54.4\%). Those who do have phones, attend class more than those who own an active phone but do not attend class, by almost $6 \%$. Likewise, those who have smartphones registered $23.75 \%$ of attendance to the $12.55 \%$ of non-attendance of those who own smartphones. The percentage of those who do not attend class and do not have smartphones $(23.76 \%)$ is similar to those who attend class but do not have smartphones (19.12\%) (Table 19).

Table 19. Have a smartphone (ages 15-17)

\begin{tabular}{ccccc}
\hline & \multicolumn{2}{c}{ Attend class } & \multicolumn{2}{c}{ Do not attend } \\
\cline { 2 - 5 } & $\mathrm{n}$ & $\%$ & $\mathrm{n}$ & $\%$ \\
\hline Yes & 199770 & $23.75 \%$ & 18174 & $12.55 \%$ \\
No & 160775 & $19.12 \%$ & 34427 & $23.76 \%$ \\
NA & 480476 & $57.13 \%$ & 92264 & $63.69 \%$ \\
Total & 841021 & $100.00 \%$ & 144864 & $100.00 \%$ \\
\hline
\end{tabular}

On the other hand, where technology is still concerned, as high as $89.86 \%$ of those who attend class, have had access to a computer in the past 12 months, compared to $47.11 \%$ of those who do not attend class and have not had access to a computer. Nevertheless, the percentages of non-attendance of both those who have used a computer in the past year $(48.12 \%)$ is quite similar to those who have not used a computer in the past year (47.11\%). There seems to be no notable difference between having and not having used a computer where class attendance is concerned (Table 20). 
Table 20. Have used a computer in the past 12 months (ages 15-17)

\begin{tabular}{ccccc}
\hline & \multicolumn{2}{c}{ Attend class } & \multicolumn{2}{c}{ Do not attend class } \\
\cline { 2 - 5 } & $\mathrm{n}$ & $\%$ & $\mathrm{n}$ & $\%$ \\
\hline Yes & 755747 & $89.86 \%$ & 69713 & $48.12 \%$ \\
No & 62321 & $7.41 \%$ & 68249 & $47.11 \%$ \\
NA & 22953 & $2.73 \%$ & 6902 & $4.76 \%$ \\
Total & 841021 & $100.00 \%$ & 144864 & $100.00 \%$ \\
\hline
\end{tabular}

There are similar statistics between those who have had access to a computer over the past 12 months and those who have accessed the Internet over the same period of time, suggesting that those who have had access to the internet, have done so through the computer. Conversely, up to $90.13 \%$ of those who attend class have had access to the internet, quite similar to the $89.86 \%$ of those who attend class and have used a computer over the past 12 months. Although it may be tempting to assume that having access to the Internet improves class attendance, what is probably more likely is that the school provides access to the Internet (Table 21).

Table 21. Have used the Internet in the past 12 months (ages 15-17)

\begin{tabular}{ccccc}
\hline & \multicolumn{2}{c}{ Attend class } & \multicolumn{2}{c}{ Do not attend class } \\
\cline { 2 - 5 } & $\mathrm{n}$ & $\%$ & $\mathrm{n}$ & $\%$ \\
\hline Yes & 757974 & $90.13 \%$ & 70808 & $48.88 \%$ \\
No & 60094 & $7.15 \%$ & 67154 & $46.36 \%$ \\
NA & 22953 & $2.73 \%$ & 6902 & $4.76 \%$ \\
Total & 841021 & $100.00 \%$ & 144864 & $100.00 \%$ \\
\hline
\end{tabular}

The largest representation of those who attend class comes from the mountain and coastal regions. In fact, almost half of the population (49.85\%) who attend class are from the coastal region, followed by $44.14 \%$ who are from the mountain region. A very small percentage (5.91\%) of the school attending population from the sample, comes from the Amazon Region. Curiously, the highest percentage of those who do not attend class, also comes from the coastal region $(59.19 \%)$ (Table 22).

Table 22. Native region (ages 15-17)

\begin{tabular}{ccccc}
\hline & \multicolumn{2}{c}{ Attend class } & \multicolumn{2}{c}{ Do not attend class } \\
\cline { 2 - 5 } & $\mathrm{n}$ & $\%$ & $\mathrm{n}$ & $\%$ \\
\hline Mountain Region & 371200 & $44.14 \%$ & 49581 & $34.23 \%$ \\
Coastal Region & 419230 & $49.85 \%$ & 85742 & $59.19 \%$ \\
The Amazon Region & 49677 & $5.91 \%$ & 9477 & $6.54 \%$ \\
Insular Region & 914 & $0.11 \%$ & 64 & $0.04 \%$ \\
Total & 841021 & $100.00 \%$ & 144864 & $100.00 \%$ \\
\hline
\end{tabular}

Around $90.45 \%$ of the population sampled who attend class, cannot be categorized in any of the job-related activities stated, which would appear to have its logic given the fact that the sample represents the age group of 15 to 17 year olds. Similarly, a high percentage of those who do not attend class (58.75\%), also belong to the "not applicable" category compared to that of those who do not attend class. Nevertheless, as high as a quarter of the population $(24.89 \%)$ who do not attend class, are dedicated to agriculture, livestock farming, hunting, forestry and fishing. Nevertheless, given the relatively high attendance rate among Ecuadorian teenagers, it may be reasonable to conclude (at least, in this decade) that for the most part, those who attend class do not have jobs and that it may be an important but not a predominant contributing factor to school absenteeism (Table 23). 
Table 23. Type of activity (ages 15-17)

\begin{tabular}{lcccc}
\hline & \multicolumn{2}{c}{ Attend class } & Do not attend class \\
\cline { 2 - 5 } & $\mathrm{n}$ & $\%$ & $\mathrm{n}$ & $\%$ \\
\hline Agriculture, livestock farming, hunting, forestry and fishing & 46867 & $5.57 \%$ & 36051 & $24.89 \%$ \\
Mining and quarrying & 5394 & $0.64 \%$ & 3240 & $2.24 \%$ \\
Distribution of water and drainage & 0 & $0.00 \%$ & 71 & $0.05 \%$ \\
Construction & 678 & $0.08 \%$ & 4392 & $3.03 \%$ \\
Commerce and vehicle repair & 14996 & $1.78 \%$ & 8840 & $6.10 \%$ \\
Transport and storage & 1129 & $0.13 \%$ & 1518 & $1.05 \%$ \\
Accomodation and food storage & 5562 & $0.66 \%$ & 2875 & $1.98 \%$ \\
Information and communication & 1418 & $0.17 \%$ & 242 & $0.17 \%$ \\
Professional, scientific and technical activities & 185 & $0.02 \%$ & 41 & $0.03 \%$ \\
Aministrative services and support & 471 & $0.06 \%$ & 505 & $0.35 \%$ \\
Teaching & 0 & $0.00 \%$ & 55 & $0.04 \%$ \\
Social services and health & 1180 & $0.14 \%$ & 0 & $0.00 \%$ \\
Arts, entertainment and recreation & 115 & $0.01 \%$ & 186 & $0.13 \%$ \\
Other service activities & 1555 & $0.18 \%$ & 1304 & $0.90 \%$ \\
Domestic services in private homes & 801 & $0.10 \%$ & 435 & $0.30 \%$ \\
NA & 760669 & $90.45 \%$ & 85109 & $58.75 \%$ \\
Total & 841021 & $100.00 \%$ & 144864 & $100.00 \%$ \\
\hline
\end{tabular}

On the other hand, when we look at job suitability under the "activity status" variable, we can appreciate that as many as $41.25 \%$ of the teenagers who do not attend class, are involved in some form of employment (whether it be "suitable employment", "underemployment due to insufficient work time", "underemployment due to insufficient earnings", "other unsuitable employment" or "unpaid employment"), indicating that these adolescents, although not well represented in numbers in the formal job sector, may well be involved in higher numbers in the informal job sector (Table 24). In terms of job activity, the vast majority of the surveyed teenagers $(90.36 \%)$ who attend class declared that they were economically inactive, followed by $7.70 \%$ who attend class but exercise some form of unpaid employment. Similarly, the highest percent of those who do not attend class are also from the economically inactive category $(53.59 \%)$, which is somewhat to be expected since these statistics represent a very young sector of the population, teenagers between the ages of 15 and 17.

The second highest percentage in the non-attendance column, however, comes from the "unpaid employment" category $(14.39 \%)$, followed by the category of "other unsuitable employment" $(13.13 \%)$. Additionally, $5.21 \%$ of those who do not attend class are in unsuitable employment. If we were to calculate the percentage of teens between the ages of 15 and 17 who do not attend class and are involved in some form of employment, then the percentage would be as high as $32.73 \%$. Conversely, $6.21 \%$ of those who do not attend class declared themselves to be in the category of underemployment due to insufficient work, which indicates the intention to find employment, signifying that a little under half of the surveyed population who do not attend class either need to be or would rather be working.

Table 24. Activity status (ages 15-17)

\begin{tabular}{lcccc}
\hline & \multicolumn{2}{c}{ Attend class } & \multicolumn{2}{c}{ Do not attend class } \\
\cline { 2 - 5 } & $\mathrm{n}$ & $\%$ & $\mathrm{n}$ & $\%$ \\
\hline Suitable job & 1193 & $0.14 \%$ & 7547 & $5.21 \%$ \\
Underemployment due to insufficient work & 3320 & $0.39 \%$ & 8994 & $6.21 \%$ \\
Underemployment dues to insufficient income & 914 & $0.11 \%$ & 3347 & $2.31 \%$ \\
\hline
\end{tabular}




\begin{tabular}{lcccc}
\hline Other unsuitable employment & 10125 & $1.20 \%$ & 19021 & $13.13 \%$ \\
Unpaid employment & 64799 & $7.70 \%$ & 20847 & $14.39 \%$ \\
Open unemployment & 468 & $0.06 \%$ & 3558 & $2.46 \%$ \\
Hidden unemployment & 277 & $0.03 \%$ & 3917 & $2.70 \%$ \\
Economically inactive population & 759925 & $90.36 \%$ & 77633 & $53.59 \%$ \\
Total & 841021 & $100.00 \%$ & 144864 & $100.00 \%$ \\
\hline
\end{tabular}

In fact, Colbert de Arboleda, Himes, and Mendez (1994) hold that many employment surveys, apart from being mainly preoccupied with the urban population, are more concerned with the formal job sector as opposed to the informal one where the vast majority of adolescents work either part or full time. The ENEMDU survey has three options under the "activity status" that could possibly be used to address this gap regarding informal job related activities ("unpaid work", "other service activities" or "domestic services in private homes") but they are inadequate. This means that there is a failure to recognise "excessive home-based work" (Colbert de Arboleda, Himes, \& Mendez, 1994) in which many of the young girls are involved, in addition to the fact that much of the information concerning the informal sector is difficult to come by since they are related to illegal and hazardous activities.

The greater part of the students who go to school (72.94\%) are not poor but the majority of the students who do not attend school are also not poor (63.51\%). Nevertheless, there is a higher percentage of subjects who do not attend class who are poor (35.9\%) than those who attend class who are poor $(26.03 \%)$. That said, however, given the fact that the majority of the students who do not attend class are not poor (63.51\%), it would appear that poverty does not have as big of an impact on the level of non-attendance as is normally assumed (Orazem, Sedlacek, \& Tzannatos, 2009) or at least that the influence of poverty on attendance levels has been reduced (INEC, 2015) (Table 25).

Table 25. Income poverty (ages 15-17)

\begin{tabular}{ccccc}
\hline & \multicolumn{2}{c}{ Attend class } & \multicolumn{2}{c}{ Do not attend class } \\
\cline { 2 - 5 } & $\mathrm{n}$ & $\%$ & $\mathrm{n}$ & $\%$ \\
\hline Not poor & 613464 & $72.94 \%$ & 91997 & $63.51 \%$ \\
Poor & 218918 & $26.03 \%$ & 52132 & $35.99 \%$ \\
NA & 8638 & $1.03 \%$ & 734 & $0.51 \%$ \\
Total & 841021 & $100.00 \%$ & 144864 & $100.00 \%$ \\
\hline
\end{tabular}

The same pattern is reflected in the statistics of extreme poverty, in the sense that the majority of the 15 to 17 year old students who attend class $(89.79 \%$ ), are not indigent, a large majority which is repeated in those who do not attend class yet are not indigent (85.51\%). Nevertheless, the statistics show that the percentage of those who do not attend class and are indigent is slightly higher (13.98\%) than the percentage of those who do attend class and are indigent $(9.19 \%$ ) (Table 26). Consequently indigence, like poverty, would still seem to have an impact on non-attendance.

Table 26. Extreme income poverty (ages 15-17)

\begin{tabular}{ccccc}
\hline & \multicolumn{2}{c}{ Attend class } & \multicolumn{2}{c}{ Do not attend class } \\
\cline { 2 - 5 } & $\mathrm{n}$ & $\%$ & $\mathrm{n}$ & $\%$ \\
\hline Not indigent & 755119 & $89.79 \%$ & 123878 & $85.51 \%$ \\
Indigent & 77263 & $9.19 \%$ & 20251 & $13.98 \%$ \\
NA & 8638 & $1.03 \%$ & 734 & $0.51 \%$ \\
Total & 841021 & $100.00 \%$ & 144864 & $100.00 \%$ \\
\hline
\end{tabular}




\section{The Hierarchical Analysis}

The hierarchical analysis consisted of five groups which are illustrated below in Figure 1 (Stefos \& Koulianidi, 2016; Sarmiento et al., 2016).

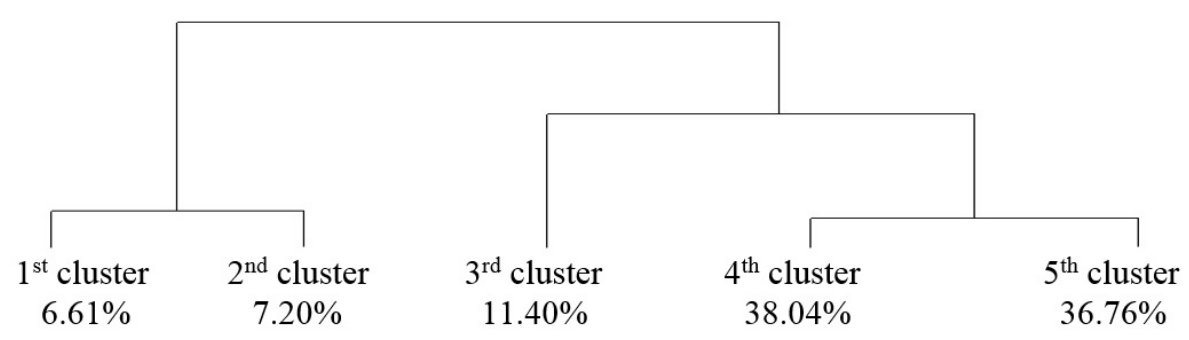

Figure 1. The classification chart

\section{First cluster $(6.61 \%$ of the sample)}

The subjects of the first group are housewives, the majority of whom are either pregnant or in the period of lactation, and who do not go to class because they lack the economic resources to do so. This group also represents subjects who have not used a computer in the past 12 months.

\section{Second cluster $(7.20 \%$ of the sample)}

The people of the second group have also responded that they do not go to class due to lack of funds. They are, nonetheless, content with their field of work, which is agriculture and livestock farming. The majority of these workers live in rural areas.

Third cluster ( $11.40 \%$ of the sample)

Some of the surveyed subjects of the third group also work in agriculture and livestock farming while others have unpaid jobs. Nevertheless, similar to group two, they are content with their line of work, although, unlike group two, these subjects attend school. They live in the rural areas and the majority of them are indigenous people.

\section{Fourth cluster (38.04\% of the sample)}

The fourth group consists of young men who are single and who attend class. They live in urban areas and the majority of them are on the morning shift.

Fifth cluster (36.76\% of the sample)

The fifth group is made up of female students on the morning shift, who in general, do not think of themselves as poor. Additionally, unlike the women of the first group, the majority of whom are either pregnant or in the nursing stage, they have used a computer in the past 12 months.

These differences between the groups are illustrated in Figure 2 where the Correspondence Analysis graph (factorial level 1x2) displays the centroids of the five groups in the two axes. In addition to this, it defines the differences and similarities between the subjects of the five groups (Benzécri, 1992). 


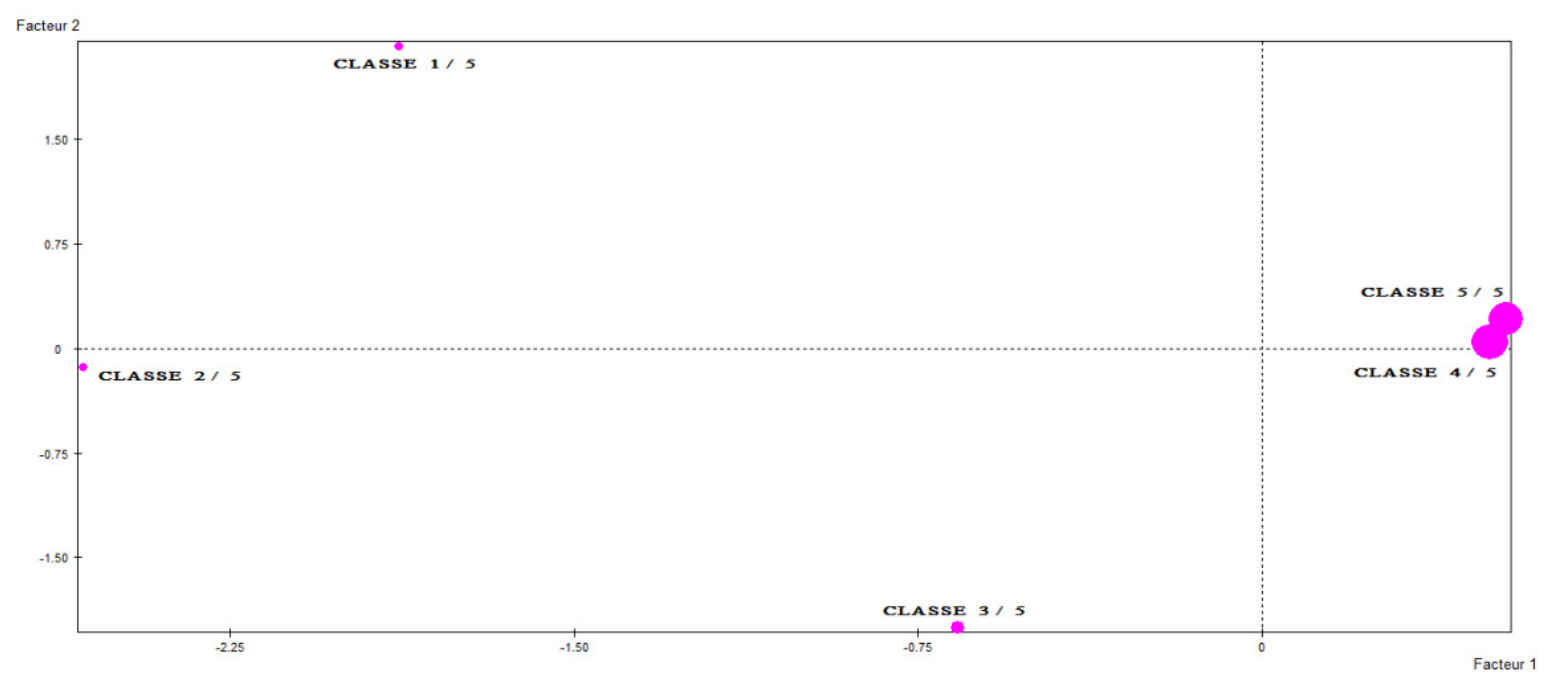

Figure 2. Analysis of multiple correspondences

\section{Conclusion}

A simple comparative analysis between the percentages of Ecuadorian adolescents between the ages of 15 and 17 enrolled in (72.91\%) and attending school $(71.81 \%)$ in 2006 as opposed to those enrolled in $(85.44 \%)$ and going to school $(85.31 \%$ ) in 2015 (INEC, 2006, 2015), is indicative of the fact that Ecuador is on the path to achieving some of the principal objectives laid out in the Decennial Plan of Education (MEC, $n / d$ ). Nevertheless, change not only calls for a change in numbers but a transformation in economic conditions and mentality as well. Historically in Latin America and in Ecuador in particular, poverty has made the school going population of children and young adolescents vulnerable to obligatory labour, particulary among the indigenous population in rural areas (Orazem, Sedlacek, \& Tzannatos, 2009).

López and Tedesco (2002) talk about the place of school being "usurped" by consumption and hence, the market in youth culture in which more prominence is given to the present than to the future. This implies that the young people of today may be more concerned about the immediate gratification of consumption permitted by money, than the less tangible expectant long term benefits of a good education (Stefos \& Efstathiou, 2013). However, despite the fact that the statistical data were insufficient to provide conclusive evidence regarding changing attitudes in the population towards education, we were able to determine certain characteristics among the 15 to 17 year olds surveyed regarding attendance:

- The ratio of enrolment to attendance within the respective age groups of 5 to 14 year olds and 15 to 17 year olds was basically the same.

- Nevertheless, there is a 12 percent drop in both enrolment and attendance between 15 to 17 year olds and 5 to 14 year olds.

- The percentage of students who attend class from the urban areas (67.74\%) is roughly twice the amount of those who attend from the rural areas $(32.26 \%)$.

- The gender gap between boys (51.93\%) and girls (48.17\%) between the ages of 15 and 17 who attend class is very minimal. This slight difference may be attributable to maternity $(2.47 \%$ of the girls surveyed cited "pregnancy" as the principal reason for not attending class and as much as $12.95 \%$ of the girls who become pregnant or are breastfeeding do not attend class) although there is no conclusive evidence of this in the data collected.

- $\quad$ Fifteen year olds have the lowest percentage of truancy (19.67\%) as opposed to the 17 year olds who have the highest $(48.10 \%)$.

- A very small percentage of the surveyed teenagers attend night school $(1.74 \%)$, with the vast majority attending school in the morning (70.77\%). This may itself be indicative of the low incidence of students in the work force. 
- $\quad$ The majority of the adolescents in this study speak Spanish as their first language (91.47\%), ruling out the language barrier as one of the possible explanations for non-attendance in this age group.

- The majority of the subjects who attend class identified themselves as mestizos (79.65\%), although an equally high percentage of this ethnic group make up the majority of those who do not attend class $(72.05 \%)$.

- Regarding the status of inactivity, the great majority of those who attend class (90.03\%) have no other activity but school. Despite this, however, more than a quarter of the population who do not attend class $(27.76 \%)$ are "housewives" and another $24.89 \%$ are involved in agriculture, livestock farming, hunting, forestry or fishing. Hence, to some extent adolescent labour (whether formal or informal) would seem to have some sort of impact on school attendance.

- With regard to the cost of education, roughly one third (32.54\%) of the subjects surveyed declared the lack of economic funds as the principal reason for not attending school. As it stands, poor students make up the minority of the adolescents who attend school (26.03\%) and also the minority (albeit a larger minority) of those who do not attend school (35.99\%), leading us to believe that poverty may still be an influential factor in school attendance in Ecuador.

- $\quad$ The percentage of indigent students who do not attend class $(13.88 \%)$ is higher than those who do $(9.19 \%)$.

- Although the majority of students who attend school are not apparently involved in any job related activities, the degree of happiness on the job of those who are may adversely affect attendance as the number of students who attend class and are happy in their jobs is almost a third (8.32\%) of those who are satisfied with their jobs and do not attend class $(27.76 \%)$.

- The type of institution attended would also appear to affect attendance, with the highest percentage of attendance $(81.17 \%)$ being found in public schools as opposed to the percentage of students who attend school and are from private schools (14.54\%). Due to insufficient data, it is difficult to assess, however, whether this is due to a larger number public as opposed to private schools, a greater number of students enrolled in public schools or simply a stricter policy in public schools with regards to attendance.

- With relation to technology, there is not a huge difference between students who attend class and have an activated cellular phone (42.87\%) and those who attend class but do not have an activated cellular phone $(54.4 \%)$. More than an indicator of the likelihood of attendance, the possession or not of an activated cellular could be taken as indicative of the economic status of the student as more than half of the population who do not attend class (58.93\%) do not own a cellular phone, which brings us back to the relationship between limited economic funds and school attendance.

- On the other hand, with regards to non-attendance, there seems to be no notable difference between those students who do not attend class and have had access to a computer over the past 12 months $(48.12 \%)$ and those who do not attend class and have not had access to a computer in the past year $(47.11 \%)$.

- In terms of region, the coastal (49.85\%) and the mountain (44.14\%) regions make up the vast majority of the school attending population, although the highest percentage of truancy comes from the coastal region $(59.19 \%)$.

In the framework of this study, a multidimensional statistical analysis was performed, which confirmed the results of the descriptive analysis (Valdivieso et al., 2017; Stefos et al., 2011). The statistical sources of information were able to shed light on the general characteristics of the school attending population of 15 to 17 year olds, nevertheless, there is still need for further studies particularly as they relate to informal work done by adolescents for family members (immediate or otherwise), which may be a hindrance to attendance (Koulianidi \& Stefos, 2015; Stefos \& Papapostolou, 2013). Additionally, information concerning attitudes towards education in both the adolescent and adult populations, the characteristics of the student's home environment and the quality of the education imparted (UNESCO, 2014) is needed in order to determine with more accuracy the factors which influence attendance. Only then will we be able to gain insight into the present state of education in Ecuador and the degree to which the recent changes in the educational system has led to an improvement in the lives of its most vulnerable citizens (Kampouropoulou et al., 2015; Stefos, 2015).

\section{Acknowledgments}

We would like to express our deepest gratitude to the Faculty of Humanities of the University of the Aegean for donating the statistical software SPAD v.4.5 used in this study. 


\section{References}

Athanasiadis, I. (1995). Correspondence Analysis and Hierarchical Classification (pp. 51-56). Athens: New Technologies Editions.

Benzécri, P. (1992). Correspondence Analysis Handbook. New York: Dekker.

Castellano, J. M., Stefos, E., \& Williams, G. L. G. (2017). The Educational and Social Profile of the Indigenous People of Ecuador: A Multidimensional Analysis. Review of European Studies, 9(1), 137-147. https://doi.org/10.5539/res.v9n1p137

Colbert de Arboleda, V., Himes, J., \& Mendez, E. (1994). Child Labour and Basic Education in Latin America. $A$ proposed UNICEF Initiative. Florence: UNICEF. Rertieved from https://www.unicef-irc.org/publications/pdf/essay6_eng.pdf

Instituto Nacional de Estadística y Censos-INEC. (2006). Encuesta Nacional de Empleo, Desempleo y Subempleo-ENEMDU, 2006. Quito, Ecuador.

Instituto Nacional de Estadística y Censos-INEC. (2015). Encuesta Nacional de Empleo, Desempleo y Subempleo-ENEMDU, 2015. Quito, Ecuador.

Instituto Nacional de Estadística y Censos-INEC. (2015). Trabajo infantil en Ecuador: Hacia un entendimiento integral de la problemática. Quito, Ecuador: UNICEF. Rertieved from https://www.unicef.org/ecuador/ LIBRO-UNICEF-FINAL-BAJA.pdf

Kampouropoulou, M., Fokiali, P., Efstathiou, I., Koutris, T., \& Stefos, E. (2015). Students' Views on the Use of a Virtual Educational Museum. Review of European Studies, 7(11), 1-6. https://doi.org/10.5539/res.v7n11p1

Koulianidi, G., \& Stefos, E. (2015). Consequences of Dietary Habits and Endocrine Disruptors in School Performance of Children Aged 10-12 in Greece. American Journal of Food Science and Nutrition, 2(6), 113-120.

López, N., \& Tedesco, J. (2002). Challenges for Secondary Education in Latin America. In CEPAL Review 76 (pp. 56-67). Rertieved from http://repositorio.cepal.org/bitstream/handle/11362/10862/1/76055068I_en.pdf

Ministerio de Educación y Cultura del Ecuador-MEC. (n.d.). Hacia el Plan Decenal de Educación del Ecuador 2006-2015. Rertieved from http://webcache.googleusercontent.com/search?q=cache:JIHu2YkFAm YJ:www.oei.es/historico/quipu/ecuador/Plan_Decenal.pdf $+\& \mathrm{~cd}=1 \& \mathrm{hl}=$ es\&ct=clnk\&client=firefox-b

Olivier, M. (2008). The analysis of quantitative data (pp. 86-88). Athens: Topos.

Orazem, P., Sedlacek, G., \& Tzannatos, Z. (Eds.). (2009). Child Labour and Education in Latin America. An Economic Perspective. New York: Palgrave MacMillan. https://doi.org/10.1057/9780230620100

Papapostolou, I., \& Stefos, E. (2013). Qualitative analysis on pedagogical research. Methodological approaches. In I. Papapostolou (Ed.), Educational activities. Teaching Interventions in Secondary Education (pp. 244-251). Rhodes: Evdimos Editions.

Papapostolou, I., Papapostoulou, K., \& Stefos, E. (2013). Educational Research. From Qualitative to Quantitative analysis (p. 178). Rhodes: Evdimos Editions.

Rivers, B. (2010). Truancy: Causes, Effects, and Solutions. In Education Masters. Paper 107. St. John Fisher College, Fisher Digital Publications. Rertieved from http://fisherpub.sjfc.edu/education_ETD_masters/107

Sarmiento, N. M., Paredes Proaño, A. M., \& Stefos, E. (2016). Deaths by Suicide in Ecuador: A Quantitative Data Analysis. Review of European Studies, 8(1), 145-156. https://doi.org/10.5539/res.v8n1p145

Sistema de Información de Tendencias Educativas en América Latina-SITEAL of UNESCO. (2001/2014). Perfiles de País. República del Ecuador. Buenos Aires: Argentina. Rertieved from http://publicaciones.siteal.org/perfiles-de-pais/21/republica-del-ecuador

Stefos, E. (2015). Causes of Death of Indigenous Ecuadorians. International Journal of Clinical Medicine Research, 2(6), 65-70.

Stefos, E., \& Efstathiou, I. (2013). Quantitative analysis of the data of the School of Trianta during the period of 1906-1916. In I. Papapostolou (Ed.), Educational activities. Teaching Interventions in Secondary Education (pp. 29-57). Rhodes: Evdimos Editions. 
Stefos, E., \& Koulianidi, G. (2016). Nutrition Data Analysis Using R: Applications in Higher Education. Health Sciences Research, 3(1), 10-16.

Stefos, E., \& Papapostolou, I. (2013). Research Methodology. Processes and suggestions (p. 406). Rhodes: Evdimos Editions.

Stefos, E., Athanasiadis, I., Gialamas, B., \& Tsolakidis, C. (2011). The Use of New Technologies and the Project Method in Teaching Statistics: A Case Study in Higher Education. HMS i JME, 3, 84-100.

UNESCO. (2014). Regional Report about Education for All in Latin America and the Caribbean. In Global Education for All Meting Muscat. Santiago: Santiago Office, UNESCO. Rertieved from http://www.unesco.org/new/fileadmin/MULTIMEDIA/HQ/ED/ED_new/pdf/LAC-GEM-2014-ENG.pdf

UNICEF. (2011). Acerca de la obligatoriedad en la escuela secundaria argentina. Análisis de la política nacional. Rertieved from https://www.unicef.org/argentina/spanish/doc_final_30_08.pdf

Valdivieso, G., Stefos, E., \& Lalama R. (2017). The Ecuadorian Amazon: A Data Analysis of Social and Educational Characteristics of the Population. Review of European Studies, 9(1), 120-129. https://doi.org/10.5539/res.v9n1p120

\section{Copyrights}

Copyright for this article is retained by the author(s), with first publication rights granted to the journal.

This is an open-access article distributed under the terms and conditions of the Creative Commons Attribution license (http://creativecommons.org/licenses/by/4.0/). 